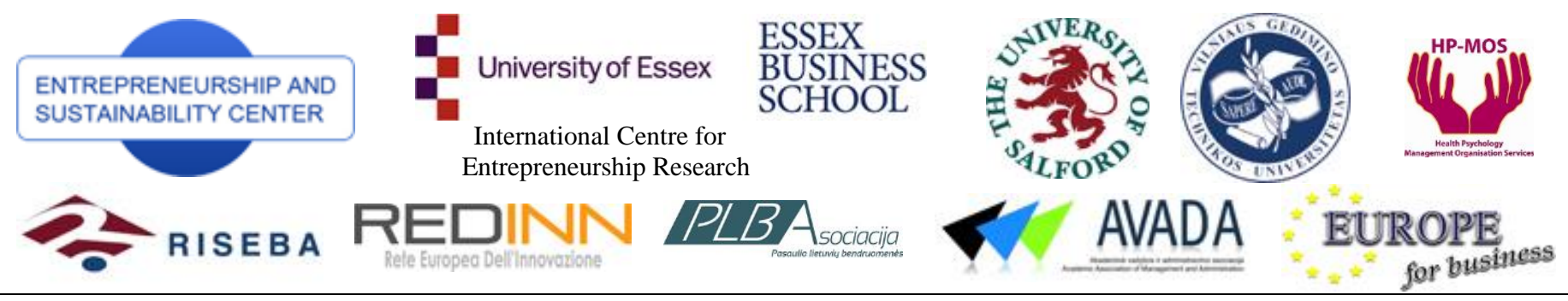

ENTREPRENEURSHIP AND SUSTAINABILITY ISSUES

ISSN 2345-0282 (online) http://jssidoi.org/jesi/

\title{
BUSINESS VALUE OF INTELLECTUAL PROPERTY IN BIOTECH SMEs: CASE STUDIES OF LITHUANIAN AND ARIZONA'S (US) FIRMS
}

\author{
Mindaugas Kiškisis, Tadas Limba², Gintarė Gulevičiūtè ${ }^{3}$ \\ 1,2, 3 Mykolas Romeris University \\ Ateities str. 20, 08303 Vilnius, Lithuania \\ E-mails:1mkiskis@mruni.eu; ${ }^{2}$ tlimba@mruni.eu, ${ }^{3}$ gintare.guleviciute@mruni.eu
}

Received 10 March 2016; accepted 20 September 2016

\begin{abstract}
The paper presents the limited quantitative and qualitative analysis of the biotechnology industries in Lithuania and Arizona (US) focusing on the role of intellectual property for the business income of the small and medium firms (SMEs). The paper also discussed theoretical aspects of the role of intellectual property in the biotech SMEs, presents empirical data on the SME intellectual property holding, employment and income data in Lithuania and Arizona based on the conducted case analysis. In depth analysis of the intellectual property, employment and revenue profile and correlations of the selected biotechnology firms are provided. Case analysis focused on patents, which are dominant and easy to study public form of intellectual property in biotechnology firms. Arizona biotechnology firms were found to especially capitalize on patents, even if the number of employees is small, while in Lithuania biotechnology firms appear to lack clear focus on on patents and instead have non-innovative intellectual property, such as trademarks. This trend is the strongest in the small firms (by the number of employees). Analysis suggests that business value of intellectual property is much higher in Arizona, and is not sufficiently ascertained in Lithuania. Analysis also shows that biotech SMEs in the US benefit from the patent focus and derive significant business value from patents, while the benefits of dispersed approach to intellectual property in Lithuania are uncertain. The authors suggest that biotech SMEs in Europe may benefit from focused patenting.
\end{abstract}

Keywords: intellectual property, patents, technology, biotechnology, SMEs

Reference to this paper should be made as follows: Kiškis, M.; Limba, T.; Gulevičiūtè, G. 2016. Business value of Intellectual Property in Biotech SMEs: case studies of Lithuanian and Arizona's (US) firms; Entrepreneurship and Sustainability Issues 4(2): $221-234$.

DOI: http://dx.doi.org/10.9770/jesi.2016.4.2(11)

JEL Classifications: K39, L26, L65

\section{Introduction}

Intellectual property rights may be described as a number of distinct property related rights with respect to intangible virtues, such as patents, copyrights, trademarks, plant varieties, not patented innovations and so on 
(Rezk et al. 2015; Rezk et al. 2016; Pauceanu 2016; Lace et al. 2015; Laužikas et al. 2015; Hofmann, Prause 2015; Lavrinenko et al. 2016; Ignatavičius et al. 2015). Intellectual property protection determines how knowledge is produced, owned and distributed (Muzaka, 2012) and is generally described as the control of the use of the protected knowledge in the market (Šitilis et al, 2016). In different countries, businesses and technology areas the role of intellectual property varies. Biotechnology is an area, where business value of intellectual property is especially important. This article analyses business value of intellectual property on the assumption that in technological firms value of the firm is defined by its' intellectual property and human capital, and this value is normally reflected in corporate earnings.

Researchers investigate what form of intellectual property is most appropriate for biotechnology firms and why specific forms are chosen. Competition between firms is growing due to globalizaton and business value of intellectual property may be a big advantage for not letting followers in an industry to copy the technology of the leader. Existing research shows that patent protection is desirable, however it is also very expensive and complicated. Thus patent focus is optimal if the firm is active in the market. Optimal policy to protect intellectual property of a firm involves market-dependent protection, since intellectual property rights inherently provide greater protection to technology leaders than those that are close to their followers. This market supported protection to the firms that are further ahead in their $R \& D$, compared to their followers increases the $R \& D$ incentives (Acemoglu, Akcigit, 2011). By employing intellectual property righs firms may increase financial assets, commercial viability, attract new investments, as well as develop new products and services (Ryder, Madhavan, 2014). For these reasons it is essential for a modern firm to select appropriate intellectual property rights for their existing technology.

The background for the paper is the case analysis of the Lithuanian and Arizona State biotechnology firms had been conducted from the perspective of the most appropriate intellectual property protection form for their intellectual assets.

Scientific issue at the heart of this paper is defined by a lack of scientific research in the comparison of the business value of intellectual property between different countries. United States has high global intellectual property business conversion, while many European countries are often considered as having problems in commercialization of the intellectual property rights. Less innovative intellectual property rights, such as trademarks, instead of patents, seem to be more accessible to the European firms. Case analysis of Arizona (US) and Lithuania biotechnology firms allows comparison of the different strategies and possibilities of intellectual property business role.

The goal of the research is to provide empirical analysis of the biotechnology business cases by presenting the situation of intellectual property business value in Lithuania and Arizona (US). The goal will be achieved through the following set of tasks such as theoretical aspects of business value of intellectual property analysis, presentation of SME intellectual property business value in Lithuania and Arizona State by conducting case analysis.

Statistical analysis, comparative empirical analysis, phenomenological, quantitative and qualitative analysis methods are used for the research presented in this paper.

\section{Theoretical aspects of intellectual property business value}

It is argued in scientific literature that intellectual property protection differs across countries (Jandhyala, 2015; Kim, et al., 2012; Lee, Mansfield, 1996; Henkel, 2014). Especially across developed and developing countries. Lee, Mansfield (1996) presented empirical studies of intellectual property rights in the developing countries and 
stressed out that firms in developing countries should be convinced that intellectual property protection is useful for the business and essential in order to break into the international marketplace. Using a panel dataset of over 70 countries, it was concluded that patent protection is important for innovations and that patentable innovations contribute to economic growth in developed countries, but less so in the developing countries (Kim, et al., 2012). Policy-makers usually assume a positive relationship between intellectual property rights and economic growth, but the empirical evidence on this question is rather inconclusive. In another research 98 countries were analysed and it was found that if measures of intellectual property protection are modified by taking into account general property rights, then there is stronger evidence for a positive relationship between intellectual property rights and economic growth (Zhang et al., 2014).

Scientific literature aims to define which type of intellectual property increases the competitiveness of innovative SMEs. The main factors affecting intellectual property and market strategies of biotech SMEs cannot be distinguished easily and are not investigated in the existing research. According to the SME case analysis in Estonia intellectual property reward regime has to be flexible and based on contractual arrangements rather than on rigid imperative legal norms (Mets, Kelli, 2013).

Patenting may be one of the most popular ways to protect intellectual property, because patent protection are strong rights and if used properly it may increase business growth. But Suzuki (2015) analysed the effects on growth of patent protection and found out that strengthening patent protection decreases the amount of common knowledge as competitors cannot freely use technological information, also, lesser disclosure of information reduces R\&D productivity. Patenting activity depends on the quality of intellectual property rights protection within a country, because it promotes new $R \& D$, only if costs on previous $R \& D$ may be recovered. In developing countries, fewer firms care about patents due to lower protection and high costs, when in developed countries higher quality protection is appreciated and firms are patenting much more (Khoury et al, 2014).

United States state of Arizona and Lithuania were selected for a case analysis based on research grant terms. These two regions have different approach and stategies of intellectual property protection and employment in business. Firms in the United States traditionally pay a lot of attention to intellectual property business value. Foreign countries that try to implement intellectual property protection systems, especially those with strong imitative ability, may attract more international business from the USA and other developed countries, and therefore may have higher business value (Awokuse, Gu, 2015). Compared to the USA, many European countries are often characterised by more technocratic and less business value focussed with respect to intellectual property rights, while the United States emerges as a key and aggressive promoter of stronger and higher global intellectual property protection standards and business value, whether multilaterally, bilaterally or unilaterally (Muzaka, 2012).

According to existing studies, in the large US firms intellectual property accounts for much of their market value: in 2009, intellectual capital - patents, copyrights, databases, brands, and organizational knowledge held a 44 percent share of US firms' overall market value (Hunter, 2016). With the conditions of ever-increasing capability in additive manufacturing, scanning, and reverse-engineering, intellectual property issues will only become more prevalent, so the current patent system should address to the digital formats of next-generation design and manufacturing systems, it is recommended to act more promptly to ensure that the data associated with digital products is protected (Kurfess, Cass, 2014). The challenge is also to increase business conversion of intellectual property. Firms experience financial losses because of intellectual property protection failures and lack of intellectual property conversion in business: domestic sales displaced by imports of infringing goods, revenue losses from fees or royalties not paid, reduced profit margins, damage to reputation or trade name, increased product liability costs, foreign piracy (Jain, 1996). In previous studies data on intellectual property protection in US multinationals firms during the period 1977-2004 were analysed and it was found out that stronger 
intellectual property protection is not important in determining overseas research and development by these multinational firms (Kanwar, 2012). Seemingly business value is much more important that just legal protection.

Situation of intellectual property in Lithuania may be described as legally perfect, but flawed from a business perspective. Article 23(1) of the Constitution of the Republic of Lithuania has extended protection to property and, as the Constitutional Court of the Republic of Lithuania has noted, that the constitutional protection of property covers not only the protection of tangible, but also of intellectual property (Mizaras, 2012). Intellectual property protection was extensively legistrated and strengthened over three decades in Lithuania, however business use and appreciation of intellectual property is still lackluster.

\section{Business value of intellectual property in Lithuanian Biotech SMEs}

Biotechnology firms in Lithuania usually select patenting in order to protect their intellectual property. The situation of Lithuanian intellectual property protection is defined by strict following of the general rules of the European and international patent law. Any invention is patentable if it is new, corresponds to an inventive level and is capable of industrial application. For the legal protection of biotechnological inventions there are special rules in the Lithuanian patent law, which state, that legal protection of biological material specific characteristics should be extended to any of the same or a different form of biological material that has the same characteristics received from the first substance. Special attention to biotechnology sector is also paid by European Union by introducing special rules for legal protection of biotechnological inventions. Biotechnology is also recognizes as a priority business area in the European Union and Lithuania. This highlights that biotechnology are playing an increasingly important role in a broad range of industries and the protection of biotechnological inventions is fundamental.

Lithuanian biotech firms also have a possibility to apply for th European patent and expand it to Lithuania. The main reasons for selecting European patent are international nature, avoidance of different regulators in different national systems, procedures simplification. Unified system is especially important in the area of biotechnology inventions in order to apply for patents on them internationally. The downsides are very high costs, lack of automatic validity and significant differences from the United States - the European Patent is not very useful for gaining protectoon in the United States.

In Lithuania there are more than 20 biotechnology firms. Some of them were established back in the late eighties, while others are set up recently and is still young and growing firms. During the EU financial period for the year 2014-2020, Lithuanian health technology and biotechnology sector will be supported by one third of the EU investments from the Smart Specialization Strategy funding administered by the Ministry of Economy. In addition, venture capital funds is now being developed, that will be available to biotechnology firms. In 2016 years in Vilnius three new biotech business incubators are going to be openned. In following table the brief summary of 12 most well known biotechnology firms operating in Lithuania is provided focussing on their technology area, their intellectual property, financial indicators. All firms' existing national patents were investigated in the patent database of the State Patent Bureau of Lithuania (Table 1).

Table 1. Data of biotechnology firms in Lithuania

\begin{tabular}{|l|l|l|l|l|}
\hline $\begin{array}{l}\text { Firm name, } \\
\text { founding years }\end{array}$ & Product/service & $\begin{array}{l}\text { Number of } \\
\text { employees in } \\
\mathbf{2 0 1 5}\end{array}$ & $\begin{array}{l}\text { Generated } \\
\text { income } \\
\mathbf{2 0 1 5}\end{array}$ & $\begin{array}{l}\text { IP strategy } \\
\text { in }\end{array}$ \\
\hline $\begin{array}{l}\text { "Profarma" Ltd, } \\
\text { registered in } 2007\end{array}$ & $\begin{array}{l}\text { Biosimilars and innovative drug products in } \\
\text { the ophthalmology, oncology/ hematology } \\
\text { and gynecology areas. }\end{array}$ & 21 & $\begin{array}{l}100-200 \\
\text { thousand } \\
\text { EUR }\end{array}$ & Patenting: 3 patents. \\
\hline "Baltymas", Ltd., & Develops superior yeast expression systems & 8 & $30-50$ & Patenting: one patent \\
\hline
\end{tabular}


The International Journal

ENTREPRENEURSHIP AND SUSTAINABILITY ISSUES

ISSN 2345-0282 (online) http://jssidoi.org/jesi/ 2016 Volume 4 Number 2 (December)

\begin{tabular}{|c|c|c|c|c|}
\hline established in 2011 & $\begin{array}{l}\text { and employs them for the synthesis of } \\
\text { improved recombinant proteins. }\end{array}$ & & $\begin{array}{l}\text { thousand } \\
\text { EUR }\end{array}$ & pending \\
\hline $\begin{array}{l}\text { "Sicor-Biotech", } \\
\text { Ltd., operating since } \\
1999\end{array}$ & Manufacture of medicines. & 214 & $\begin{array}{l}\text { More than } \\
100 \text { million } \\
\text { EUR }\end{array}$ & $\begin{array}{l}\text { Patentig: one patent } \\
\text { application,"priority" } \\
\text { application was filed } \\
\text { in } 2006 \text { to the United } \\
\text { Kingdom Intellectual } \\
\text { Property Office. }\end{array}$ \\
\hline $\begin{array}{l}\text { JSC "Biocentras", } \\
\text { founded in } 1988 .\end{array}$ & New biological products and technologies. & 38 & $\begin{array}{l}1-2 \text { million } \\
\text { EUR }\end{array}$ & $\begin{array}{lr}\text { Patenting: } & 4 \\
\text { Lithuanian patents } \\
\text { and one } & \text { PCT } \\
\text { application. } & \end{array}$ \\
\hline $\begin{array}{l}\text { "Biotechpharma" } \\
\text { Ltd., registered in } \\
2004\end{array}$ & Production and manufacturing of drugs. & 125 & $\begin{array}{l}\text { 10-20 million } \\
\text { EUR }\end{array}$ & $\begin{array}{l}\text { Patenting: } \\
\text { Lithuanian patents in } \\
\text { force, } 1 \text { international } \\
\text { and } 1 \text { European } \\
\text { patent application. }\end{array}$ \\
\hline $\begin{array}{l}\text { "Valentis" Ltd., } \\
\text { Established in } 2003\end{array}$ & $\begin{array}{l}\text { Formulate, produce and actively market } \\
\text { innovative pharmaceutical preparations. }\end{array}$ & 109 & $\begin{array}{l}\text { 10-20 million } \\
\text { EUR }\end{array}$ & $\begin{array}{l}\text { Over } 70 \text { trade marks } \\
\text { registered in } \\
\text { Lithuania. }\end{array}$ \\
\hline $\begin{array}{l}\text { "ProBioSanus" Ltd., } \\
\text { registered in } 2012\end{array}$ & $\begin{array}{l}\text { Production line of cleaning products, which } \\
\text { use probiotics }\end{array}$ & 12 & $\begin{array}{l}200-300 \\
\text { thousand } \\
\text { EUR }\end{array}$ & $\begin{array}{lr}4 & \text { registered } \\
\text { trademarks } & \text { in } \\
\text { Lithuania. } & \end{array}$ \\
\hline $\begin{array}{l}\text { "Bioeksma" Ltd., } \\
\text { Established in } 2005\end{array}$ & $\begin{array}{l}\text { Implements complex solutions of laboratory } \\
\text { equipment in medical diagnostics. }\end{array}$ & 22 & $\begin{array}{l}\text { 5-10 million } \\
\text { EUR }\end{array}$ & $\begin{array}{l}\text { Patenting: patented } \\
\text { at least two } \\
\text { inventions in the } \\
\text { field of laser optics } \\
\text { (currently patents are } \\
\text { invalid), } 1 \text { European } \\
\text { patent. }\end{array}$ \\
\hline $\begin{array}{l}\text { "Innovative Pharma } \\
\text { Baltics", } \\
\text { founded in } 2008\end{array}$ & $\begin{array}{l}\text { Produces first developed medicinal plant } \\
\text { products. }\end{array}$ & 15 & $\begin{array}{l}500 \\
\text { thousand-1 } \\
\text { million EUR }\end{array}$ & $\begin{array}{lr}13 & \text { registered } \\
\text { trademarks } & \text { in } \\
\text { Lithuania. } & \end{array}$ \\
\hline $\begin{array}{l}\text { "Froceth" JSC, } \\
\text { registered in } 2012\end{array}$ & $\begin{array}{l}\text { Providing individual therapy services, which } \\
\text { uses the client's own cells, and/or tissues. }\end{array}$ & 10 & $\begin{array}{l}300-500 \\
\text { thousand } \\
\text { EUR }\end{array}$ & $\begin{array}{l}\text { No firm's registered } \\
\text { intellectual property } \\
\text { rights are found. }\end{array}$ \\
\hline $\begin{array}{l}\text { "Bioseka" Ltd., } \\
\text { established in } 2011\end{array}$ & $\begin{array}{l}\text { Developing antisense oligonucleotide } \\
\text { biotechnologies and other controls of } \\
\text { antibiotic resistance in bacteria. }\end{array}$ & 4 & $\begin{array}{l}10-20 \\
\text { thousand } \\
\text { EUR }\end{array}$ & $\begin{array}{l}\text { No firm's registered } \\
\text { intellectual property } \\
\text { rights are found. }\end{array}$ \\
\hline $\begin{array}{l}\text { "Biomé" Ltd., } \\
\text { registered in } 2014\end{array}$ & $\begin{array}{l}\text { Creates innovative biomedical materials for } \\
\text { industry. }\end{array}$ & 2 & $\begin{array}{l}\text { About } 5 \\
\text { thousand } \\
\text { EUR }\end{array}$ & $\begin{array}{lr}\text { Registered 1 trade } \\
\text { mark and } & \text { has } \\
\text { submitted } & \text { an } \\
\text { international patent } \\
\text { application. }\end{array}$ \\
\hline
\end{tabular}

Source: authors

Data about Lithuanian biotechnology firms employement and revenue was taken from the Social Security Register of Lithuanian firms.

In order to analyse the situation of Lithuanian biotechnology firms, two hypotheses have been raised:

- $\mathrm{H}_{0}$ - number of employees, number of patets and revenue correlate equally in Lithuanian biotechnology firms.

- $\mathrm{H}_{1}$ - number of employees, number of patets and revenue do not correlate equally in Lithuanian biotechnology firms. 
For the additional analysis of the examples of analysed Lithuanian biotechnology firms regression analysis and non-parametric correlation coefficient of the employment and revenue in the studied biotechnology firms are presented in Figure 1 and Table 2.

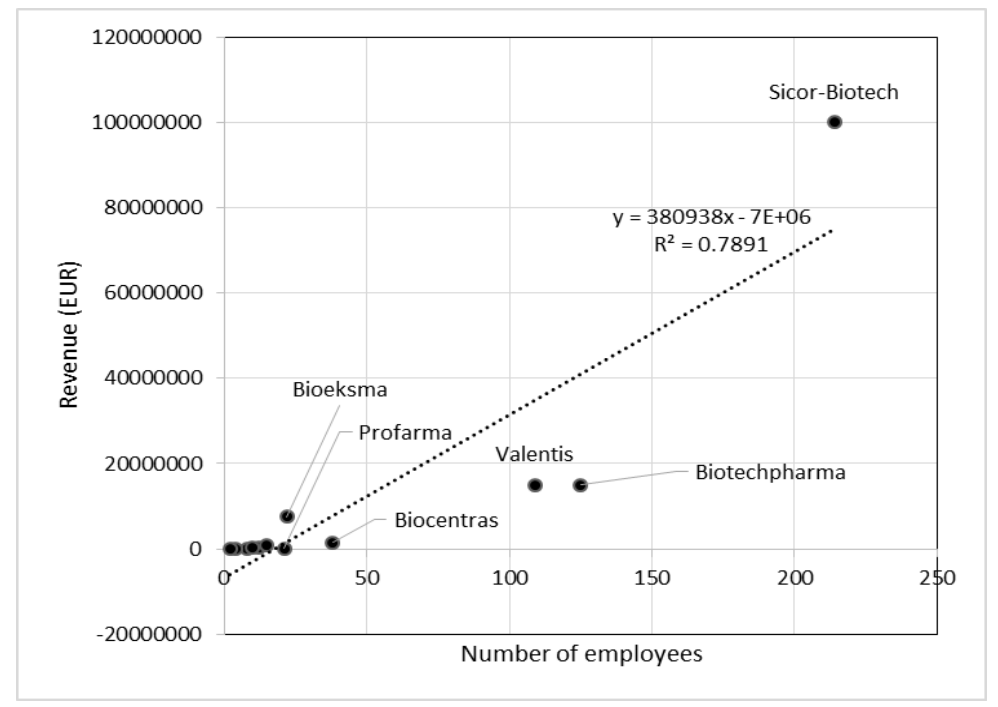

Fig.1. Regression analysis of the employment and revenue in the studied biotechnology firms in Lithuania

Source: authors.

Table 2. Non-parametric correlation coefficient for the employment and revenue in the analysed Lithuanian biotechnology firms

Symmetric Measures

\begin{tabular}{|ll|l|l|l|l|}
\hline & & Value & Asymp. Std. Error & Approx. $\mathrm{T}^{\mathrm{b}}$ & Approx. Sig. \\
\hline $\begin{array}{l}\text { Ordinal by Ordinal } \\
\text { N of Valid Cases }\end{array}$ & Kendall's tau-c & .840 & .099 & 8.521 & .000 \\
\hline
\end{tabular}

a. Not assuming the null hypothesis.

b. Using the asymptotic standard error assuming the null hypothesis.

Source: authors

Regression analysis is justified since the coefficient is $>0.25$. Regression analysis results shows that there is a strong correlation between employment and revenue in the Lithuanian biotechnology firms. It means that firms revenue depends on the number of employees. It may be predicted, that the more employees firm has, the more revenue it generates.

Further analysis had been done in order to understand if Lithuanian biotechnology firms' revenue correlates with number of patents held by these firms. Regression analysis is presented in Figure 2. 


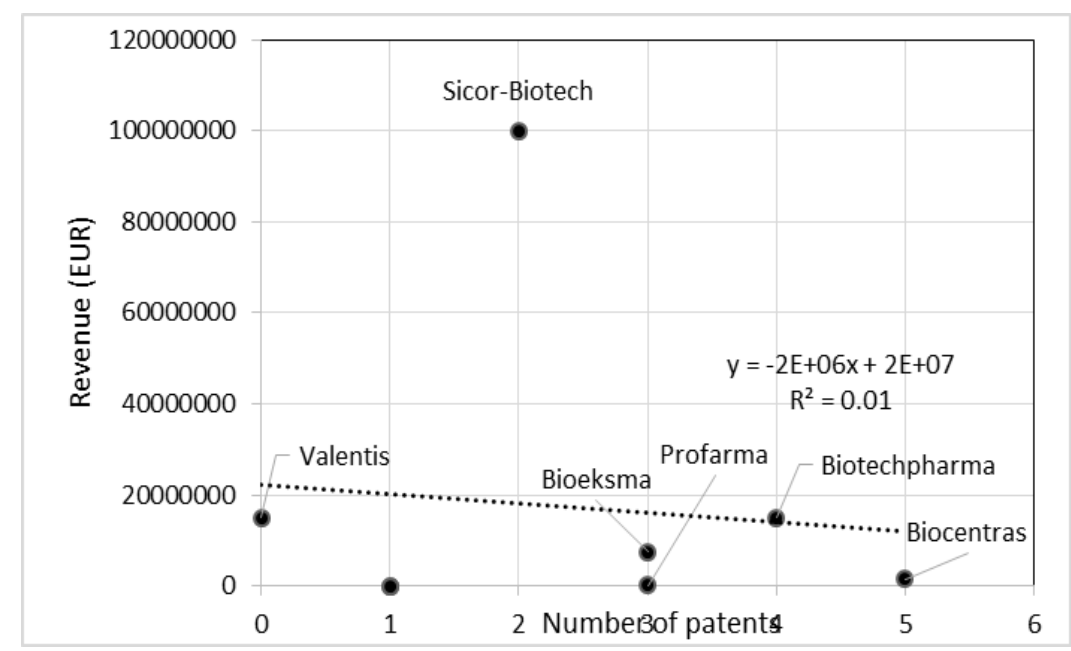

Fig.2. Regression analysis of the number of patents and revenue in the studied biotechnology firms in Lithuania

Source: authors.

Regression analysis is justified since the coefficient is $>0.25$.

Regression analysis results shows that there is no correlation between number of patents and revenue. It means that firms revenue does not depend on the number of patents, which firms have.

After analysing correlations between number of employees, number of patents and revenue in Lithuanian biotechnology firms, $\mathrm{H}_{1}$ hypothesis may be accepted, meaning that the number of employees, number of patets and revenue do not correlate equally in Lithuanian biotechnology firms. Correlations may be noticed only between number of employees and revenue, but there are no correlations between number of patents and revenue in Lithuanian biotechnology firms.

\section{Business value of intellectual property in Arizona (US) Biotech SMEs}

Biotechnology firms in USA were studied in the US state of Arizona.

Arizona was selected because this state is not national leader, however is ambitious in the biosciences in such fields as precision medicine, neurosciences, bioengineering, diagnostics, and agricultural biotechnology. This makes the the US state of Arizona more comparable to Lithuania, which is not a biotech leader in Europe, however has specific strenghts in certain bioscience areas.

The Arizona State has created BioMap, which lists the firms and organizations driving the biosciences in Arizona. This includes the state's firms, research institutes, educational institutions, research hospitals, and collaborating organizations. Arizona BioMap is operating as a guideline for a further development of biotechnology sector. The following table presents the main goals, strategies and actions, related to intellectual property strategies of the Arizona BioMap.

Table 3. Arizona State BioMap goals, strategies, actions

\begin{tabular}{|l|l|l|}
\hline BioMap Goals & Main strategies to achieve goals & $\begin{array}{l}\text { Actions, concerning intellectual property } \\
\text { strategies }\end{array}$ \\
\hline
\end{tabular}




\begin{tabular}{|c|c|c|}
\hline \multirow{3}{*}{$\begin{array}{l}\text { Entrepreneurial } \\
\text { Hub }\end{array}$} & Expand bioscience firms from startups & - \\
\hline & $\begin{array}{l}\text { Accelerate the commercialization of discoveries } \\
\text { and advancements }\end{array}$ & $\begin{array}{l}\text { Eliminate barriers to seamless intellectual property } \\
\text { flow between research-performing institutions and } \\
\text { industry }\end{array}$ \\
\hline & $\begin{array}{l}\text { Implementation of stable and predictable tax and } \\
\text { regulatory policies }\end{array}$ & - \\
\hline \multirow[t]{2}{*}{$\begin{array}{l}\text { Research into } \\
\text { practice }\end{array}$} & $\begin{array}{l}\text { Increase the competitiveness for } \mathrm{R} \& \mathrm{D} \text { funds from } \\
\text { industry, government, and philanthropy }\end{array}$ & - \\
\hline & $\begin{array}{l}\text { Partnerships among research-performing } \\
\text { institutions, industry, and foundations }\end{array}$ & - \\
\hline \multirow[t]{3}{*}{ Bio-talent } & $\begin{array}{l}\text { Increase the supply of executive-level serial } \\
\text { entrepreneurial talent within the bioscience } \\
\text { industry }\end{array}$ & - \\
\hline & Expand student entrepreneurship programs & $\begin{array}{l}\text { Link firms with workers, and enable students to } \\
\text { use and learn about tools, product development, } \\
\text { intellectual property protection through expanded } \\
\text { internship and apprenticeship programs }\end{array}$ \\
\hline & $\begin{array}{l}\text { Develop the talent base by attracting and } \\
\text { retaining top graduate students, doctoral and post- } \\
\text { doctoral candidates and trainees }\end{array}$ & - \\
\hline \multirow[t]{2}{*}{ Connectivity } & $\begin{array}{l}\text { Develop a strategy to form linkages of } \\
\text { universities, private research institutes, firms, } \\
\text { investors, and entrepreneurs in key target markets }\end{array}$ & - \\
\hline & $\begin{array}{l}\text { Encourage creative private-public partnerships } \\
\text { and financing mechanisms }\end{array}$ & $\begin{array}{l}\text { Educate and inform developers on space needs and } \\
\text { requirements of the bioscience industry (including } \\
\text { patenting) }\end{array}$ \\
\hline \multirow[t]{2}{*}{ Collaboration } & $\begin{array}{l}\text { Strengthen bioscience advocacy at the local, state, } \\
\text { and national levels }\end{array}$ & - \\
\hline & Remove growing impediments to collaboration & - \\
\hline
\end{tabular}

Source: authors.

Arizona State BioMap presents five main goals accompanied by strategies and actions. Intellectual property protection plays an important role in accelerating biotechnology sector: Arizona BioMap stresses out seamless intellectual property flow between research-performing institutions and industry, importance of learning about intellectual property protection, patenting. Mainly intellectual property protection is defined in three strategies of BioMap: Entrepreneurial Hub, Bio-talent, Connectivity.

For the case analysis 12 biotechnology firms operating in Arizona were available. The research focussed on their work practices, their intellectual property, financial indicators. All firms' revenue and employement data about was taken from America's Small Business register. The main data is briefly summarised in the following table.

Table 4. Data of biotechnology firms in Arizona State

\begin{tabular}{|l|l|l|l|l|}
\hline $\begin{array}{l}\text { Firm name, } \\
\text { founding years }\end{array}$ & Product/service & $\begin{array}{l}\text { Number of } \\
\text { employees }\end{array}$ & $\begin{array}{l}\text { Generated } \\
\text { income }\end{array}$ & IP strategy \\
\hline $\begin{array}{l}\text { "Attometrics", } \\
\text { registered in 2013 }\end{array}$ & $\begin{array}{l}\text { Uses a novel technology capable of } \\
\text { rapidly detecting protein, metabolite } \\
\text { and DNA analytes with } \\
\text { unprecedented sensitivity. }\end{array}$ & 3 & 134120 EUR & Patenting: holds 5 patents. \\
\hline $\begin{array}{l}\text { "HealthTell", Ltd., } \\
\text { established in 2011 }\end{array}$ & Focuses on early disease detection. & 9 & 670601 EUR & Patenting: 3 patents \\
\hline $\begin{array}{l}\text { "ARBSource", } \\
\text { established in 2010 }\end{array}$ & Focuses on wastewater treatment. & 5 & 268240 EUR & $\begin{array}{l}\text { Patenting: has filed for 3 } \\
\text { patents, and exclusively } \\
\text { licenses an additional 5 } \\
\text { patents. }\end{array}$ \\
\hline
\end{tabular}


The International Journal

ENTREPRENEURSHIP AND SUSTAINABILITY ISSUES

ISSN 2345-0282 (online) http://jssidoi.org/jesi/ 2016 Volume 4 Number 2 (December)

\begin{tabular}{|c|c|c|c|c|}
\hline $\begin{array}{l}\text { "Viomics", founded } \\
\text { in } 2011 .\end{array}$ & $\begin{array}{l}\text { Discovers, develops and delivers } \\
\text { paradigm-changing cancer detection } \\
\text { technologies to enable early and } \\
\text { targeted intervention that cures } \\
\text { previously deadly cancers. }\end{array}$ & 3 & 214592 EUR & Patenting: 5 patents. \\
\hline "SiO2 Nano Tech" & $\begin{array}{l}\text { Uses silicon dioxide in its patented } \\
\text { technology VitreOx to control } \\
\text { fogging due to condensation on } \\
\text { medical devices and athletic eyewear. }\end{array}$ & 19 & 447067 EUR & Patenting. \\
\hline $\begin{array}{ll}\text { "Fast } & \text { PCR } \\
\text { Diagnostics" } & \end{array}$ & $\begin{array}{l}\text { Has a technology that amplifies and } \\
\text { quantifies the presence of a specific } \\
\text { DNA/RNA sequence. }\end{array}$ & 2 & 125179 EUR & Patenting. \\
\hline "Adesto technology" & $\begin{array}{l}\text { Develops conductive bridging RAM } \\
\text { nonvolatile memory technology. }\end{array}$ & 49 & $\begin{array}{l}17882697 \\
\text { EUR }\end{array}$ & $\begin{array}{l}\text { Patenting: in developing } \\
\text { CBRAM technology has } \\
\text { strong patent portfolio ( } 9 \\
\text { patente). Has forging } \\
\text { licensing agreements with } \\
\text { SOC partners. }\end{array}$ \\
\hline "Instant Bio Scan" & $\begin{array}{l}\text { Developes an optical scanning } \\
\text { machine that monitors water quality } \\
\text { for medical, industrial, municipal and } \\
\text { numerous other uses. }\end{array}$ & 7 & 742132 EUR & Patenting: 4 patents. \\
\hline $\begin{array}{l}\text { "Desert } r \text { Sweet } \\
\text { Biofuels", established } \\
\text { in } 2009\end{array}$ & $\begin{array}{l}\text { Produces first developed medicinal } \\
\text { plant products. }\end{array}$ & 70 & 894135 EUR & Patenting. \\
\hline $\begin{array}{l}\text { "Fertizona", } \\
\text { registered in } 1994\end{array}$ & $\begin{array}{l}\text { Sells various liquid and dry fertilizers, } \\
\text { agricultural chemicals, seed and other } \\
\text { agricultural related products. }\end{array}$ & 49 & $\begin{array}{l}89413484 \\
\text { EUR }\end{array}$ & $\begin{array}{l}\text { No firm's registered } \\
\text { intellectual property rights } \\
\text { are found. }\end{array}$ \\
\hline $\begin{array}{l}\text { "Vitron", } \\
\text { established in } 1991\end{array}$ & $\begin{array}{l}\text { Provide methodology for optimally } \\
\text { preparing and incubating tissue slices }\end{array}$ & 4 & 35765 EUR & $\begin{array}{l}\text { No firm's registered } \\
\text { intellectual property rights } \\
\text { are found. }\end{array}$ \\
\hline $\begin{array}{l}\text { "Luceome } \\
\text { Biotechnologies", } \\
\text { registered in } 2007\end{array}$ & Biological Research. & 4 & 259299 EUR & $\begin{array}{l}\text { No firm's registered } \\
\text { intellectual property rights } \\
\text { are found. }\end{array}$ \\
\hline
\end{tabular}

Source: authors.

In order to analyse the situation of Arizona biotechnology firms, two hypotheses have been raised:

- $\mathrm{H}_{0}$ - number of employees, number of patets and revenue correlate equally in Arizona biotechnology firms.

- $\mathrm{H}_{1}$ - number of employees, number of patents and revenue do not correlate equally in Arizona biotechnology firms.

Regression analysis and non-parametric correlation coefficient of the employment and revenue were also calculated in the studied biotechnology firms in Arizona State. The results are presented in Figure 3 and Table 5. 


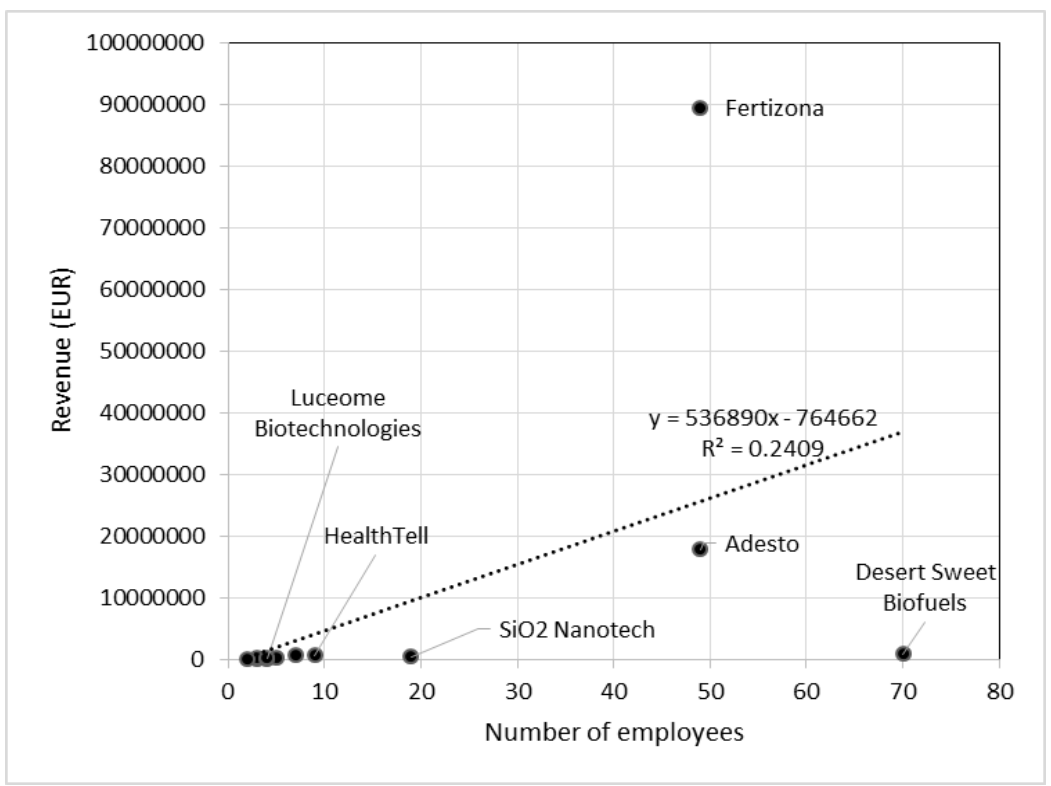

Fig.3. Regression analysis of the employment and revenue in the studied biotechnology firms in Arizona State

Source: authors.

Table 5. Non-parametric correlation coefficient for the employment and revenue in the analysed Arizona State biotechnology firms

\begin{tabular}{l} 
Symmetric Measures \\
\begin{tabular}{|l|l|l|l|l|}
\hline & Value & Asymp. Std. Error & Approx. $\mathrm{T}^{\mathrm{b}}$ & Approx. Sig. \\
\hline $\begin{array}{l}\text { Ordinal by Ordinal Kendall's tau-c } \\
\text { N of Valid Cases }\end{array}$ & .734 & .091 & 8.100 & .000 \\
a. Not assuming the null hypothesis. \\
b. Using the asymptotic standard error assuming the null hypothesis.
\end{tabular} \\
\hline
\end{tabular}

Source: authors.

Regression analysis is justified since the coefficient is $>0.25$, however in this case the coefficient is 0,249 and it may be concluded, that there are no correlation between number of employees and revenue of Arizona State biotechnology firms. It means that firms revenue does not depend on the number of employees. Analysed biotechnology firms may demonstrate big revenue and do not have a lot of employees. This suggests that revenue is generated by intellectual property, rather than by the employment.

Further analysis had been done in order to understand if Arizona biotechnology firms revenue correlates with number of patents of firms. Regression analysis is presented in Figure 4. 


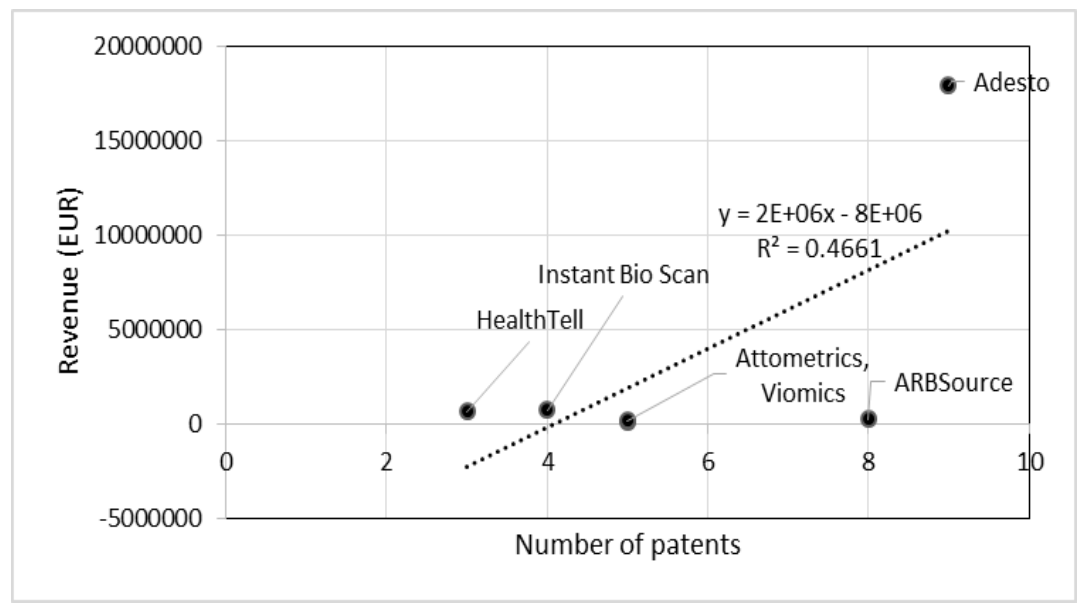

Fig.4. Regression analysis of the number of patents and revenue in the studied biotechnology firms in Arizona State

Source: authors.

Regression analysis is justified since the coefficient is $>0.25$.

Regression analysis results shows that there is correlation between number of patents and revenue in Arizona State analysed firms. It means that firms revenue depends on the number of patents, which firms have. This further substantiated the former conclusion that intellectual property is the driver of business revenue in the Arizona State biotechnology firms.

After analysing correlations between number of employees, number of patents and revenue in Arizona biotechnology firms, $\mathrm{H}_{1}$ hypothesis may be accepted. That is, number of employees, number of patets and revenue do not correlate equally in Arizona biotechnology firms. Correlations may be noticed only between number of patents and revenue, but there are no correlations between number of employees and revenue in Arizona biotechnology firms.

\section{Conclusions}

Business value of intellectual property differs across countries. United States has high global intellectual property protection standards and strong focus on the commercial purpose of intellectual property - to generate business value. Many European countries are often defined as having technocratic legal approach to intellectual property rights, when business value of intellectual property is not appreciated. As a result of this, less innovative intellectual property rights seem to be more popular in such countries as Lithuania.

Biotechnology industry is a priority industry in Europe and the US. In Lithuania there are more than 20 biotechnology firms and growing biotechnology contribution to the economy. The US is the global leader in biotechnology.

The analysis of the paper focused on empirical study of Lithuanian and the US State of Arizona biotechnology firms. Twelve firms were selected for analysis in Lithuania. For the analysis of USA biotechnology industry Arizona State was selected because this state is not a national leader, but is very ambitious in the specific biosciences. The same may be said about Lithuania. Twelve Arizona biotechnology firms were selected for closer analysis. 
After comparing results of empirical study of Lithuania and Arizona State biotechnology firms the main conclusions are that Arizona biotechnology firms especially capitalize on patents and generate their revenue from intellectual property, even if the number of employees is small, while in Lithuania biotechnology firms appear not to be able to extract revenue from their intellectual property. Employee labor seems to be the source of revenue in the Lithuanian biotechnology firms, based on the results of the analysis.

The employment and revenue profile and correlations of the selected biotechnology firms in Lithuania and Arizona State showed big differences: in Lithuania firms revenue depends on the number of employees and it may be predicted, that the more employees firm has, the more revenue it generates, while in Arizona State revenue does not depend on the number of employees and firm may have a huge revenue despite the small number of employees. Further analysis showed that there are no correlations between number of patents and revenue in Lithuanian biotechnology firms, but there is a correlation between number of patents and revenue in Arizona biotechnology firms.

Further research with larger data samples may be needed to fully validate these findings, however the analysis clearly enough demonstrates the differences of revenue, employment and intellectual property profile in Lithuania and Arizona State. This suggests that Lithuanian biotechnology firms need to develop an intellectual property commercialization strategy and need to focus on converting intellectual property into revenue in their target markets, rather than just trying to patent their technology somewhere.

These findings are applicable not only to Lithuania, but also for other smaller European Union countries, which have ambitions to develop biotechnology science and business.

*The article is published under the research, which is funded by Lithuanian Research Council under the measure „Support to Researcher Teams' Projects” (grant No. MIP-14446, name of the project "Research of Biotechnology SME's Intellectual Property Strategies').

\section{References}

Acemoglu D., Akcigit U. 2011. Intellectual Property Rights Policy, Competition and Innovation. Journal of European Economic Association, 10 (1): 1-42.

America's Small Business register. Available on the Internet: <http://www.manta.com/business>

Arizona's Bioscience Roadmap: 2014-2025 Advancing the Biosciences and Improving Health Outcomes, Available on the Internet: <http://www.flinn.org/wp-content/uploads/2014/04/arizona_s_bioscience_roadmap_2014-2025.compressed.pdf accessed 20 August 2016>

Awokuse T. O., Gu W. 2015. Does Foreign Intellectual Property Rights Protection Affect US Exports and FDI? Bulletin of Economic Research, 67 (3): 256-264.

Directive 2004/48/EC of the European Parliament and of the Council of 29 April 2004 on the enforcement of intellectual property rights. Official Journal L 195, 02/06/2004.

Directive 98/44/EC of the European Parliament and of the Council of 6 July 1998 on the legal protection of biotechnological inventions, Official Journal L 213, 30/07/1998 P. 0013 - 0021

Henkel S. 2014. Identification and Motivation of High Potentials to Keep Their Intellectual Property in the Firm. Germany: Anchor. 
Hofmann, B.; Prause, G. 2015. How to keep open-source based innovation approaches sustainable: a view from the intellectual property perspective, Entrepreneurship and Sustainability Issues 2(3): 133-141. http://dx.doi.org/10.9770/jesi.2014.2.3(2)

Hunter R. 2016. Incentivizing Innovation: The Imperative of Intellectual Property Protection. Brown Journal of World Affairs, 22 (2): 161 172.

Ignatavičius, R.; Tvaronavičienè, M.; Piccinetti, L. 2015. Sustainable development through technology transfer networks: case of Lithuania, Journal of Security and Sustainability Issues 4(3): 261-267. http://dx.doi.org/10.9770/jssi.2015.4.3(6)

Jain S. 1996. Problems in International Protection of Intellectual Property Rights. Journal of International Marketing. 4 (1): 9-32.

Jandhyala S. 2015. International and domestic dynamics of intellectual property protection. Journal of World Business, 50 (2): $284-293$.

Kanwar S. 2012. The Location of Overseas Research and Development and Intellectual Property Protection. Journal of Development Studies, 48 (10): 1453-1469.

Khoury T., Cuervo-Cazurra A., Dau L. A. 2014. Institutional Outsiders and Insiders: The Response of Foreign and Domestic Inventors to the Quality of Intellectual Property Rights Protection. Global Strategy Journal, 4 (3): 200-220.

Kima Y., Leeb K., Parkc W., Chood K. 2012. Appropriate intellectual property protection and economic growth in countries at different levels of development. Research Policy, 41 (2): 358-375.

Kurfess T., Cass W. 2014. Rethinking Additive Manufacturing and Intellectual Property Protection. Research Technology Management, 57 (5): $35-42$.

Lace, N.; Buldakova, N.; Rumbinaitè, G. 2015. Organizational creativity as a driving force for company's innovative development, Entrepreneurship and Sustainability Issues 3(2): 137-148. http://dx.doi.org/10.9770/jesi.2015.3.2(2)

Laužikas, M.; Tindale, H.; Tranavičius, L.; Kičiatovas, E. 2015. Effects of consumer behaviour on innovations in fast food industry, Entrepreneurship and Sustainability Issues 3(1): 85-103. http://dx.doi.org/10.9770/jesi.2015.3.1(8)

Lavrinenko, O.; Ohotina, A.; Tumalavičius, V.; Pidlisna, O. V. 2016. Assessment of partnership development in cross-border regions' innovation systems (Latvia-Lithuania-Belarus), Journal of Security and Sustainability Issues 6(1): 155166. http://dx.doi.org/10.9770/jssi.2016.6.1(12)

Lee J., Mansfield E. 1996. Intellectual Property Protection and U.S. Foreign Direct Investment. The Review of Economics and Statistics, 78 (2): 181-186.

Lithuanian firms revenue and employement data. Available on the Internet: < http://rekvizitai.vz.lt/en/>

Lithuanian Patent law, State News, 2011-01-10, No. 4-127

Mizaras V. 2012. Issues of Intellectual Property Law in the Jurisprudence of the Constitutional Court of the Republic of Lithuania. Jurisprudence, 19 (3): 1111-1130.

Muzaka V. 2012. Intellectual property protection and European "competitiveness". Review of International Political Economy, 20 (4): 819 847.

Pauceanu, A. M. 2016. Innovation and entrepreneurship in Sultanate of 0man - an empirical study, Entrepreneurship and Sustainability Issues 4(1): 83-99. http://dx.doi.org/10.9770/jesi.2016.4.1(8)

Rezk, M. A.; Ibrahim, H. H.; Radwan, A.; Sakr, M. M.; Tvaronavičiené, M.; Piccinetti, L. 2016. Innovation magnitude of manufacturing industry in Egypt with particular focus on SMEs, Entrepreneurship and Sustainability Issues 3(4): 306318. http://dx.doi.org/10.9770/jesi.2016.3.4(1) 
Rezk, M. A.; Ibrahim, H. H.; Tvaronavičienè, M.; Sakr, M. M.; Piccinetti, L. 2015. Measuring innovations in Egypt: case of industry, Entrepreneurship and Sustainability Issues 3(1): 47-55. http://dx.doi.org/10.9770/jesi.2015.3.1(4)

Rosha, A.; Lace, N. 2015. Sustainable development and behavioural patterns: to innovations through coaching, Journal of Security and Sustainability Issues 5(2): 171-180. http://dx.doi.org/10.9770/jssi.2015.5.2(4)

Ryder R., Madhavan A. 2014. Intellectual Property and Business: The Power of Intangible Assets. Los Angeles: Sage Publications.

Štitilis D., Kiškis M., Limba T., Rotomskis I., Agafonov K., Gulevičiūtè G., Panka K. 2016. Internet and Technology Law. Vilnius: Mykolas Romeris universitety.

Suzuki K. 2015. Economic growth under two forms of intellectual property rights protection: patents and trade secrets. Journal of Economics, 115 (1): 49-71.

Tvaronavičienė, M.; Černevičiūtè, J. 2015. Technology transfer phenomenon and its impact on sustainable development, Journal of Security and Sustainability Issues 5(1): 87-97. http://dx.doi.org/10.9770/jssi.2015.5.1(7)

Zhang J., Du D., Park W. G. 2014. How Private Property Protection Influences the Impact of Intellectual Property Rights on Economic Growth? Global Economic Review, 44 (1): 1-30.

Mindaugas KIŠKIS is the Professor at Mykolas Romeris University in Vilnius, Lithuania. Prof. M. Kiskis main areas of research and expertise are - intellectual property, technology (bio-nano-ICT) management, regulation and policy; digital content and digital media, privacy and data protection issues. Prof. Kiskis also works in e-business, innovation and entrepreneurship fields. Prof. Kiskis is a fellowships recipient with major foreign universities, including Visiting Professor at the East China University of Science and Technology (2013), Understanding Canada Scholar (2011), Fulbright Scholar at the Arizona State University (2007-2008), Markle Fellow at the Oxford University (2003) and other. Prof. M. Kiskis is also the serial entrepreneur, cofounder of three technology start-ups, active member of the knowledge society NGOs, also, the author of 4 monographs, 4 textbooks and 35 articles in Lithuanian and foreign publications.

ORDCHID ID: orcid.org/0000-0003-4269-375X

Tadas LIMBA is Assoc. prof. at Mykolas Romeris University, Lithuania. He has published over 20 articles in Lithuanian and foreign scientific journals, monograph, textbook, focused on e-government and e-business. His additional areas of research and expertise are - IT law regulation and policy; digital content, digital media, privacy and data protection issues. Tadas Limba is a member of Lithuanian Computer Society since 2007. Since 2013 he is Asia Center Board Member, South Korea's representative at Mykolas Romeris University. $\mathrm{He}$ is visiting professor at Zaragoza University in Spain. He plays an active role in international communication and development of joint double degree studies program with South Korea Dongseo University.

ORDCHID ID: orcid.org/0000-0003-2330-8684

Gintarė GULEVIČIŪTĖ is a PhD student (in Management) and lecturer at Mykolas Romeris University, Lithuania. Her areas of interest are e-business, e-marketing, entrepreneurship, business communication and digital contents. She plays an active role in international communication and development of joint double degree study programs with South Korea Dongseo University.

ORDCHID ID: orcid.org/0000-0003-1974-3982

Copyright (C) 2016 by author(s) and VsI Entrepreneurship and Sustainability Center

This work is licensed under the Creative Commons Attribution International License (CC BY).

http://creativecommons.org/licenses/by/4.0/

cc) (7) Open Access 